\title{
ASSESSMENT OF VOLATILE ORGANIC COMPOUND (VOCS) IN MULTI-STOREY SHOPPING MALL IN MALACCA MALAYSIA
}

\author{
R Zirwatul Aida R Ibrahim and Raja Zirwatul ‘Adawiah Raja Ibrahim \\ ${ }^{1}$ School of Social and Economic Development, Universiti Malaysia Terengganu, 21030 Terengganu, Malaysia \\ ${ }^{2}$ Department of Facility, Environment, Safety \& Health, Texas Instruments, Electronics Malaysia Sdn Bhd, 75350 \\ Batu Berendam, Melaka, Malaysia
}

* Corresponding author: R Zirwatul Aida R Ibrahim

Email: zirwatul@umt.edu.my

\begin{abstract}
This study investigates the mall's Indoor Air Quality (IAQ) to compare changes in levels of Volatile Organic Compounds (VOCs) concentration in the morning and evening. It also explores the sources of emission released that could be related to occupants' health status (dizziness, headaches, flu, running nose, nose stuffy, nose irritation, eye irritation, watery eye, and eye reddening). A questionnaire survey approach was used to collect quantitative data involving 32 workers from malls in Malacca, Malaysia. This study established models to measure changes in VOCs level in two different sessions for a given area. Also, predictors related to the work context (human performance and condition) were found to be significantly related to occupants' symptoms. Two significant values identified the changes in VOCs concentration for morning and evening sessions in the lobby, bakery, eye ware shop, mobile centers, and supermarket. No evidence supports the exposure towards the personal individual in the present findings. This study contributes to the literature on levels of VOCs in the shopping mall as well as the emission sources. It also suggests that more comprehensive monitoring can be achieved, particularly in the context of Malaysia.
\end{abstract}

Keywords: Volatile Organic Compounds, Indoor Air Quality, Mall, Malaysia

\section{INTRODUCTION}

Massive environmental pollution is interconnected to some of the implemented regulatory measures as protection of public health, protect quality of air and regulate or ban ozone $\left(\mathrm{O}_{3}\right)$. The main focus in protecting public health today is to control of air pollution. The study showed homes air, office buildings and schools are contaminated by several gaseous and particulate substances that may exist an insufficient concentration level that causes acute and chronic symptoms or illness in a exposed person. The exposure can be varied due to the exposure period that approximately 8 hours per day in the office, commercial and institutional buildings from 16 to 24 hours per day in homes. The Indoor Air Quality (IAQ) includes nine common parameters in the measurement which are carbon dioxide $\left(\mathrm{CO}_{2}\right.$ carbon monoxide $(\mathrm{CO})$, respirable suspended particulate (RSP), nitrogen dioxide $\left(\mathrm{NO}_{2}\right)$, ozone $\left(\mathrm{O}_{3}\right)$, formaldehyde $(\mathrm{HCHO})$, total volatile organic compounds (TVOC), radon (Rn) and airborne bacteria count $(A B C)^{1}$. Besides, other major indoor pollutants that pose potential health risks in buildings such as asbestos, combustion products, aldehydes, VOCs, semi-volatile organic compounds (SVOCs), pesticides and some of the biological contaminants. In the middle of $1980 \mathrm{~s}$, WHO introduced SBS as a reference of symptoms that is associated with the poor indoor climate in a building. Nowadays, occupational medicine of indoor air quality becomes highlighted by most of the researches which emphasized on the pathomechanism of specific symptoms There is no definite etiology that indicates the direct combination of symptoms with exposure to indoor pollutants. Several risk factors have been identified, such as eye symptoms ${ }^{2}$. Previous studies $^{3,4}$ have identified that a shopping mall is a basic place for daily urban life, which be defined as a multifunctional public urban spaces, which can devote to VOCs exposure and affects their health. In Malaysia, shopping malls are a primary place for leisure for Malaysians for shopping, meeting people, working and many more. They probably spend hours in the shopping mall especially commercial buildings or shopping malls that include offices. Therefore, the monitoring of VOCs is an important parameter to assess indoor air quality. The Department of Occupational Safety and Health Malaysia enforced the Occupational Safety and Health Act (Act 514) since 1994. Safety and health of employees shall be provided by the employer that had been enforced in this act. Moreover, it is a way to evade employees from exposure to an accident and risk ${ }^{5}$.

\section{LITERATURE REVIEWS}

\section{Pollution of Indoor Air}

Environmental factors which are Thermal Comfort (TC), Indoor Air Quality (IAQ), Acoustic Comfort (AC) and Visual Comfort (VC) are the combination that contributed of Indoor environmental comfort. A lot of cases showed that natural ventilated indoor environments more comfortable compared than fully conditioned environments ${ }^{6}$. 
IAQ perception is divided into two different types, which are acute and delay perception. The acute perception is immediate development when person enters the building and delayed perception is build while workday. Olfaction or stimulation of the olfactory nerve normally associated with acute perceptive and is grouped as immediately perceived IAQ. Otherwise, the delayed perceptive is a combination of symptoms between olfaction and sensory irritation.

This also may cause trigeminal nerve endings stimulation. The deteriorated environmental and occupational risk factors also lead to possible action. For instance, the increase in room temperature while working and prolonged hours working on the computer are part of risk factors. Hence, the olfactory and trigeminal have different stimulation rates due to the aspect of time, as previously claimed on the perceived IAQ and pollutants analysis association ${ }^{2}$.

\section{Indoor Air Pollutants Sources}

The conventional approach for building design material selection is primarily based on factors such as cost, aesthetic values, availability and durability $^{7}$. Two contributions factors to the increase of air pollution, which are primary pollutants and secondary pollutants. The primary pollutants are directly emitted from primary sources while secondary pollutants are primary pollutants reactions with other pollutants in an environment that has sunlight, humidity or both ${ }^{7}$. The sources of indoor air quality problems may vary which include external factors and conditions, furnishing and materials, occupants and mechanical system.

The main cause of a contaminant or pollutants from outside of a building originates from areas that are close to the road or highways, which are contaminated with smoke from the vehicles' exhaust ${ }^{7}$. Examples of air pollution sources are paints, glues, insulation and other building materials that are used as interior decorations which may emit VOCs during the installation process $^{8}$.

An organic compound is determined as a compound which contains hydrogen and carbon such as octane, sugar, and butane. It is also known as a volatile organic compound (VOCs) because the organic compounds evaporated easily. Human health and comfort of the indoor environment may get the direct adverse effect of VOCs exposure. Therefore, higher quantities or long periods of VOCs exposure may cause an unsafe condition because the classification of VOCs is mostly carcinogenic and toxic. The health effects that may be identified by long periods of VOCs exposure are dizziness, nausea, and headaches. Nevertheless, the effect of long-term exposure of certain VOCs, such as benzene may cause cancer or death ${ }^{9}$. Inhalation is the main route of entry for VOCs, which allows them to enter the human body and this is hard to prevent ${ }^{8}$.

There are many ways to improving problems of IAQ, such as through building mechanical systems. Recently, IAQ problems in facilities have occurred, as the mechanical equipment is not properly operated including the intake of damper problems, improper strategies control or malfunction control, negative building pressure and breathing zone ventilation (BZV). The negative pressure only happens once the unplanned entry of additional balancing air comes into space and contributes to the contamination. Moreover, the ground level pollutants (such as mold, radon, and vegetation decay) entry could be caused by the negative pressure of pollutant building contribution. Besides, the damper intake of outside air (OA) may also improve IAQ problems in the building. The improper close of damper would allow dirt and moisture to come into spaces and develop mold germination ${ }^{8}$.

The improper operation control and maintenance lead to many perspectives of poor indoor air quality and increase the operation cost. This will also cause poor environmental condition and imbalance of systems. The ventilation is important to improve the air quality problem, but then again, it is not the main method to solve this kind of problem in all buildings that do not provide proper control. The most critical part in supplying air is to provide the needs of Breathing Zone Ventilation (BZV) inhabitants. This focus on the actual occupant's breathing area and space in the facility contributed by the outside air ventilation. The real-location space in the building is easier to be implemented compared to the mechanical system solution. Lastly, there are categories of occupant-originated contaminants, which contains normal odors, cosmetic odors and exhaled carbon dioxide $\left(\mathrm{CO}_{2}\right)^{8}$.

Otherwise, volatile organic compounds (VOCs) and formaldehyde $\left(\mathrm{CH}_{2} \mathrm{O}\right)$, ozone $\left(\mathrm{O}_{3}\right)$, nitrogen dioxide $\left(\mathrm{NO}_{2}\right)$ and sulfur dioxide $\left(\mathrm{SO}_{2}\right)$, particulate matter (PM), microbial and passive smoke are also pollutants of indoor air quality ${ }^{10}$.

\section{Volatile Organic Compounds (VOCs)}

Chemical analysis and sensory evaluation identify adverse health effects of indoor air pollutants (TVOCs). There is study indicated that different chamber tests had investigated the emissions and surface material odor in ambient air under standardized conditions. Chemical analysis (concentrations of TVOC) and sensory evaluation (such as odor intensity, receiving air) was conducted after the building materials were exposed to a uniform. The essential connection that resulting in large amounts of indoor volatile organic compounds (VOCs) is materials of indoor 
finishes in the building materials (such as floors, walls, and ceilings) that considered as an important role in apparent indoor air quality.

Therefore, building materials are the premier indoor air pollution sources either used as an interior or as furnishings that caused by humans and their activities, and HVAC systems. Enhance, materials of indoor surface may act as an absorbent agent or emission of VOC sources. Furthermore, the pollutant emission able to transmit to another material. The pollutants concentration pollutants and apparent air quality able to reduce by process. However, only porous materials have significant level of absorption on the VOCs ${ }^{7}$.

At or above threshold of VOCs concentration, the odor of threshold normally induce the olfaction system. The irritant odor or unpleasant odor, is the cumulative effect of repeated unpleasant odor over a given period. Association of olfaction health and symptoms were reported in three different ways;

1. Thresholds between sensory irritation and olfaction. The concentration at and above the odor threshold was considered the odor perception factor.

2. The threshold for sensory irritation generally dominated sensory irritation. However, the odor may coexist.

3. The adverse of health effects such as moldy related species like endotoxin had occurred at a concentration below the threshold for sensory irritation where additional odorous compounds coexisted with other indoor air pollutants.

\section{Health Impact of Indoor Air Pollutant}

The VOCs is second indoor-generated gaseous contaminant and become impact and health concern in workplace ${ }^{11}$. There is a challenge in decreasing the environmental, mental impact, where it is a crucial aspect to comprehend the occupants interactions with the indoor environment due to the needs in providing comfortable conditions in the most efficient way. Groups of five drivers were identified that might manipulate the occupant's behavior; physical environment (odour, temperature, humidity, air velocity, noise and illumination), contextual (indirect factors such as building insulation, heating system type and thermostat-type), psychological (needs satisfaction such as safety, health, thermal comfort, visual comfort and acoustic comfort), physiology (age, gender, health status, clothing, activity level and foods intakes) and social (interaction between occupants such as opening or closing of windows $)^{12}$.
The volatile organic compounds (VOCs), formaldehyde and ozone are the main causes of indoor air pollution. These organic pollutants are characterized as carcinogenic, immune-toxic, allergenic, neurotoxic, and irritant or sick building syndrome (SBS) indicators ${ }^{13}$. Normally, the respiratory system is the main route of entry for these toxic allergens entering the human body. However, some of the allergens directly give adverse effect to the lungs and attack the blood system or lymphatic system and harm bodily organs. The five categories which are irritation, allergies, cell damage, fibrosis, and oncogenesis may lead to lung disease ${ }^{14}$.

The symptoms such as discomfort, diseases; mucous membrane irritation, irritation headaches, and fatigues may have occurred due to the exposure of VOCs or other pollutants in high or low concentrations. The symptoms may associate with each other while exposed ${ }^{13}$ there are recognized association of air pollution and asthma ${ }^{15}$.

Indoor air pollution is associated with cardiovascular and pulmonary problems. Besides, it showed that the inflated blood pressure and heart rate in youth are related to indoor particle exposure. Nonetheless, the exposure of VOCs is may decrease human heart rate variability (HRV) and increasing serum $\mathrm{C}$-reactive protein (CRP) in young adults. However, avoidance of VOCs sources will give a low effect on cardiovascular ${ }^{13}$.

\section{Impact of VOCs}

Healthcare construction projects incorporate inferior finishes and products categorized as reduced or non-toxic, low-VOC or PVC free. Besides, building materials give major impact on the air quality and able to effect the occupants, especially toward sensitive persons, including children, elderly and patients with anemic immunity or have respiratory problems $^{6}$. Psychological, psychosocial and physical factors were reprted might result in health and comfort effects. The IAQ comfort is recognized by perception odor, eye and upper airway sensory irritation in the additional organic pollutants effect and daily effects exposure repetitively, lower airway effects, human factors (such as anxiety or stress). The odor capable to deteriorate the performance of occupants as it possibly cause mental, cognitive and visual distraction ${ }^{2}$.

Discussion on the occupants impacts, especially employees in a shopping mall caused by the VOCs emission. The new VOCs emission may occur due to different of chemical substances are present in modern building products, household, and furnishings. The study shows VOCs was released through building materials, furnishing and household product while usage and it considered as sources of reactive compounds. Two types of 
VOCs emission divided into primary emission (new product's compound released) and secondary emission (produced compound by chemical reaction either in the product of in indoor condition). Sample of three cases were discussed to elaborate on these emissions. In the first case, an unwanted reaction occurred while forming a reaction. The second case exposed that the unwanted reaction occurred at the surface or in different materials at the occupant's site (example between concrete, adhesive and flooring material). The last case is an unwanted reaction of primary compounds with other primary compounds or reactive gases in the gas phase at the occupant's site ${ }^{16}$.

Limitation of VOCs level by major sources which are building materials shall be controlled since the VOCs are responsible for health hazards and a mal-odorous atmosphere ${ }^{17}$.

Based on the literature, the following research objectives were constructed:

RO1: To compare the level of VOCs concentration in the morning and evening session at the shopping mall.

RO2: To identity, the sources of VOCs emission released that could be related to mall occupants' health.

\section{METHODOLOGY}

\section{Respondent and Study Area}

The studied shopping mall is located in Ayer Keroh Malacca, Malaysia. The mall has three floors. The ground floor is a hypermarket, the second-floor houses clothing, bakery, toys, and other small stores. Offices and a cinema occupy the third floor. The mall is installed with central aircondition and smoking is not allowed.

Using convenience sampling, 32 mall occupants were surveyed in this study comprising 14 (43.8\%) males and $18(56.3 \%)$ females. In the initial stage of data collection, the questionnaires were distributed to 50 participants, however, due to incomplete and missing data, the number reduced to 32 (64\% response rate) which is acceptable ${ }^{18}$.

\section{Research Instrument}

There were two stages of data collection:

\section{Self-Administered Questionnaires}

The questionnaires are divided into four parts, including demographic information, indoor air quality, time exposure and overall subjective rating of perception to the indoor area. The main objective of the self-administered questionnaire is to ascertain the general response of the participants regarding the quality of the shopping mall indoor environment.

\section{Field Monitoring}

Field monitoring is a method to identify and compare the level of VOCs in the morning and evening. The VOCs meter, PID Analyser 102 Plus was introduced by HNU Systems to get the measurements in direct reading while monitoring. This PID analyzer is a single handheld unit that is suitable for inorganic and organic measurement which could be ionized by a UV lamp $(9.5,10.2$, 10.6 and 11.7). The process of ionization happens once a photon of sufficient energy is absorbed by a molecule and results in the formation of an ion plus and electron. The measurement completed in two sessions, namely in the morning $(8.30 \mathrm{am})$ and the evening $(4.30 \mathrm{pm})$. The flow rate used for this measurement is $>0.2 \mathrm{l} / \mathrm{min}$, and it has less than 1 second to $90 \%$ response time. The range probe of this instrument is 0.1 to $3000 \mathrm{ppm}$ instrument is 0.1 to $3000 \mathrm{ppm}$.

\section{Data Analysis}

\section{RESULT}

With reference to Table 1 , the results show that 32 respondents were involved in this 18 of whom were women. Referring to the age factor, 12 (37.5\%) of respondents between age 26 and 30 years, followed by respondents aged between 17 and 20 years $(\mathrm{N}=6,18.8 \%)$. Meanwhile, four respondents between age 41 and 45 years. Statistical Package for Social Sciences (SPSS) was used in data analyzing. In terms of reporting demographic profiling and measuring participants' perception of the indoor air quality, duration of exposure and overall judgment of the shopping mall, descriptive statistics including percentage, frequency were used. Paired sample t-test also known as the repeated measure, was analyzed to measure the difference of VOCs measurement using PDI 102 Plus during T1 (8.30 am) and T2 (4.30pm).

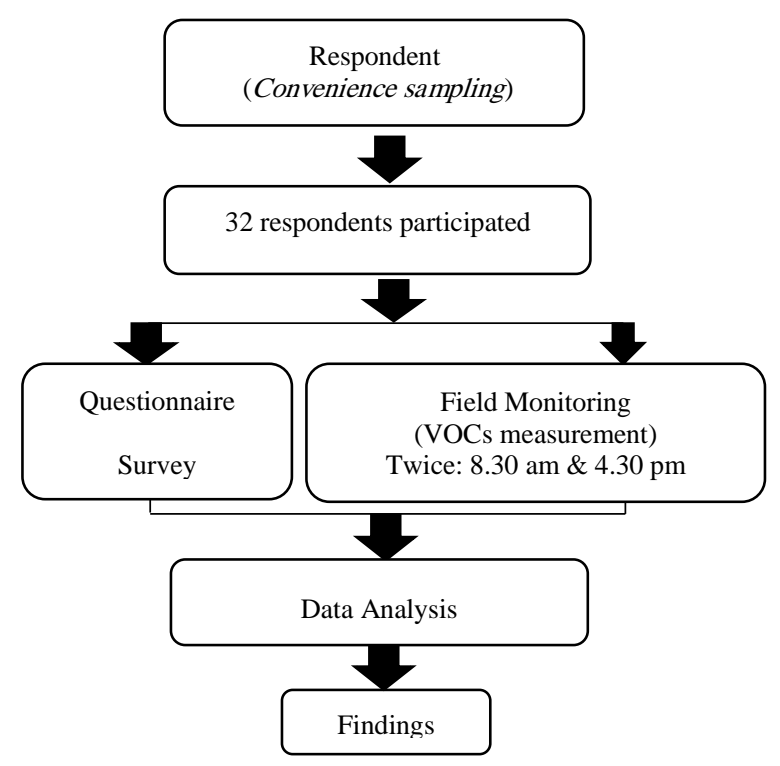

Figure 1: Data analysis flowchart 
The participation of the respondents aged 41 to 45 years was $12.5 \%(\mathrm{~N}=4)$. Similar findings were reported for the respondents aged between 21 and 25 years and 36 and 40 years. Next, the category of work shows that $56.3 \%$ of the respondents are working on the first floor. The other respondents are working on the second floor $(43.8 \%)$.

Table 1: Demographic Information

\begin{tabular}{|c|c|c|c|}
\hline \multicolumn{2}{|c|}{ Category Items } & \multirow{3}{*}{$\frac{\text { Frequency }}{14}$} & \multirow{3}{*}{$\begin{array}{l}\begin{array}{l}\text { Percent } \\
\text { age }\end{array} \\
43.8\end{array}$} \\
\hline & Male & & \\
\hline \multirow{5}{*}{ Gender } & & & \\
\hline & Female & 18 & 56.3 \\
\hline & $17-20$ years & 6 & 18.8 \\
\hline & $21-25$ years & 2 & 6.3 \\
\hline & $26-30$ years & 12 & 37.5 \\
\hline \multirow[t]{5}{*}{ Age } & $31-35$ years & 3 & 9.4 \\
\hline & $36-40$ years & 2 & 6.3 \\
\hline & 41-45 years & 4 & 12.5 \\
\hline & $\begin{array}{l}46 \text { years and } \\
\text { above }\end{array}$ & 3 & 9.4 \\
\hline & $1^{\text {st }}$ Floor & 18 & 56.3 \\
\hline \multirow{2}{*}{$\begin{array}{r}\text { Work } \\
\text { Area }\end{array}$} & & & \\
\hline & $2^{\text {nd }}$ Floor & 14 & 43.8 \\
\hline \multirow{8}{*}{$\begin{array}{l}\text { Type of } \\
\text { Work }\end{array}$} & Hypermarket & 2 & 6.3 \\
\hline & Exhibition & 1 & 3.1 \\
\hline & Fast food & 1 & 3.1 \\
\hline & Bakery & 2 & 6.3 \\
\hline & Food Court & 2 & 6.3 \\
\hline & Booths & 9 & 28.1 \\
\hline & Other & 15 & 46.9 \\
\hline & Total & 32 & 100.0 \\
\hline
\end{tabular}

Table 2 presents the indoor air quality, which has been divided into five dimensions which are air surrounding condition, smell of the area, the overall assessment of the indoor air quality, the feeling of respondents of the work area and comfort of the workers.

The results show that $68.8 \%(\mathrm{~N}=22)$ accepted the quality of air around the workplace, followed by seven (21.9\%) respondents who claimed the surrounding air was stuffy. Meanwhile, only two $(6.3 \%)$ respondents felt very stuffy, and $3.1 \%(\mathrm{~N}=1)$ respondents stated the surrounding air was fresh. Most of the respondents accepted the odor occurrences in their working area $(84.4 \%$, $\mathrm{N}=27$ ). On the other hand, some of them were unable to accept the surrounding odor at their work. This was due to leakage of the ceiling, which contributed to the dampness of carpets.

In terms of respondents' perception of the overall rating for the indoor air quality, the majority $(\mathrm{N}=23,71.9 \%)$ were satisfied with their working area. Meanwhile, the rest rated it as very good $(\mathrm{N}=1,3.1 \%)$, good $(\mathrm{N}=12,12.5 \%)$ and not satisfied $(\mathrm{N}=12,12.5 \%)$. With regards to respondents' feeling towards the working area, $78.1 \%(\mathrm{~N}=25)$ indicated neutral as their answers for their work while $15.6 \%(\mathrm{~N}=5)$ mentioned that the work areas were spacious. Only $6.3 \%(\mathrm{~N}=2)$ agreed that their work areas were crowded or cramped.

Table 2: Indoor Air Quality

\begin{tabular}{lcc}
\hline Category & Frequency & Percentage \\
\hline Opinion on Surrounding & Air & \\
Very Stuffy & 2 & 6.3 \\
Stuffy & 7 & 21.9 \\
Acceptable & 22 & 68.8 \\
Fresh & 1 & 3.1 \\
Opinion on Odour & & \\
Acceptable & 27 & 84.4 \\
Unacceptable & 5 & 15.6 \\
The overall rating for the indoor air quality opinion \\
Very good & 1 & 3.1 \\
Good & 4 & 12.5 \\
Satisfied & 23 & 71.9 \\
Not Satisfied & 4 & 12.5 \\
Feel of the work area & & \\
Spacious & 5 & 15.6 \\
Neutral & 25 & 78.1 \\
Tight & 2 & 6.3 \\
\hline
\end{tabular}

Table 3: Time of Exposure in Work Area

\begin{tabular}{lcc}
\hline Category & Frequency & Percentage \\
\hline $\begin{array}{l}\text { Less than } 8 \\
\text { hours/day }\end{array}$ & 12 & 37.5 \\
$8-14$ hours/day & 20 & 62.5 \\
Total & 32 & 100.0 \\
\hline
\end{tabular}

As shown in Table 3, more than half of the respondents $(\mathrm{N}=20,62.5 \%)$ reported that they spent almost 8 to 14 hours per day in the work area. Whereas, others $(37.5 \%-12)$ spent less than 8 hours per day. 
Table 4: Symptoms during Working Hours

\begin{tabular}{|c|c|c|c|}
\hline $\begin{array}{l}\text { Health } \\
\text { Effects }\end{array}$ & Category & Frequency & Percentage \\
\hline \multirow{5}{*}{ Nose } & $\begin{array}{l}\text { Dryness } \\
\text { Itching, } \\
\text { stinging }\end{array}$ & 12 & 37.5 \\
\hline & & 17 & 53.1 \\
\hline & $\begin{array}{l}\text { Sensation } \\
\text { Stuffy }\end{array}$ & & \\
\hline & $\begin{array}{l}\text { nose } \\
\text { Running }\end{array}$ & 1 & 3.1 \\
\hline & nose & 2 & 6.3 \\
\hline \multirow{3}{*}{ Eye } & Dryness & 10 & 31.3 \\
\hline & Watery & 14 & 43.9 \\
\hline & Reddening & 8 & 25.1 \\
\hline \multirow{4}{*}{ Others } & Headache & 11 & 34.5 \\
\hline & Dizziness & 12 & 37.6 \\
\hline & $\begin{array}{l}\text { Tired or } \\
\text { Sleepy }\end{array}$ & 9 & 28.2 \\
\hline & Total & 32 & 100 \\
\hline
\end{tabular}

The occupants experienced the health effect symptoms during working hours, and the symptoms disappeared once leaving the building. The majority of respondents $(\mathrm{N}=17,53.1 \%)$ claimed itching and stinging sensation as one cause of nasal problems, followed by dryness $(\mathrm{N}=12,37.5 \%)$, runny $(\mathrm{N}=2,6.3 \%)$ and stuffy nose $(\mathrm{N}=1,3.1 \%)$. For eye problems, the findings indicate that the majority of respondents $(\mathrm{N}=14$, $43.9 \%)$ suffered watery eyes.Ten respondents (31.3\%) claimed that they suffered dryness problem, and eight respondents $(25.1 \%)$ suffered the problem of redness. The respondents also gave other symptoms, including feeling dizzy $(\mathrm{N}=12,37.6 \%)$, headache $(\mathrm{N}=11,34.5 \%)$ and feeling tired or sleepy $(\mathrm{N}=9,28.2 \%)$ during working hours. This health effects symptoms were related to VOCs or other pollutants ${ }^{13,15}$.

Table 5 presents a field monitoring result by using the PID analyzer 102 plus. The monitoring was completed at $8.30 \mathrm{am}$ and the evening at $4.30 \mathrm{pm}$, which covers different areas. The average mean value (Ave.) of pre and post- monitoring (morning and evening) was compared using paired sample $\mathrm{t}$-test. With regards to the sources of VOCs emission in the mall, there were significant differences in area $B$ and $C$, on the second floor.

\section{DISCUSSION}

The current study investigated the difference of VOCs concentration levels in the morning and evening session at the shopping mall as well as to identity the sources of VOCs emission released that mall occupants' health. The changes in the level of VOCs between morning and evening could influence the occupants' health as well as their work performance. Most of the mall occupants spent their time more than 8 hours per day, thus, the duration of exposure towards VOCs in the building may reduce the health rate of the occupants. The B area (food courts, plastics stall and arcade) has the highest result of differences of VOCs concentration between morning and evening. The contaminants and pollutants may come from different sources, including tobacco smoke, fragrance, as well as vehicle smoke from outside the building. The possible increasing of VOCs concentration was also due to vehicle exhaust in the areas where the location of the building itself is in the vicinity of to the road. Another factor that may increase the concentration of VOCs in the evening was due to the increase in the number of occupants compared to the morning ${ }^{19}$.

\section{CONCLUSION}

In summary, this study predicts that the concentration of VOCs in the morning and evening has significant differences due to malfunction of ventilation, humidity, temperature, crowd and the size of the area. The findings reveal that the survey and monitoring were related to the health effects of the occupants in a multi-storey shopping mall and it is beneficial to the mall authorities in developing better understanding and awareness regarding IAQ at work for the wellbeing of employees.

This could give insights in scheduling the proper maintenance of ventilation systems, control of outside and inside sources of VOCs in the building reliability to ensure the safety and health of employees as stated in the Occupational Safety and Health Act (OSHA) 1994. Also, active public and mall visitor awareness involving targeted education campaigns and smoking cessation programs are useful to mitigate the negative impacts of polluted indoor air quality.

With regards to methodological limitations, this study employed a cross-sectional design with a collection of data from surveys of mall occupants within a limited period. Besides, the study focuses on general emissions of VOCs concentration in one mall only. Therefore, we could not compare the time exposure and sources that are fixed to every kind of commercial building. 
Table 5: Morning and Evening VOCs Measurement (Field Monitoring Result)

\begin{tabular}{|c|c|c|c|c|c|c|c|c|c|c|c|}
\hline Location & $\begin{array}{c}\text { Sessio } \\
\mathrm{n}\end{array}$ & \multicolumn{3}{|c|}{ Morning (ppm) } & \multirow{2}{*}{ Ave. } & \multicolumn{3}{|c|}{ Evening (ppm) } & \multirow{2}{*}{ Ave. } & \multirow[t]{2}{*}{$\begin{array}{c}\mathrm{p}- \\
\text { value }\end{array}$} & \multirow{2}{*}{ Sig } \\
\hline 1st floor & Area & S1 & S2 & S3 & & S1 & S2 & S3 & & & \\
\hline Booths & \multirow[b]{2}{*}{ A } & \multirow[b]{2}{*}{0.4} & \multirow[b]{2}{*}{0.3} & \multirow[b]{2}{*}{0.3} & \multirow[b]{2}{*}{0.3333} & \multirow[b]{2}{*}{0.3} & \multirow[b]{2}{*}{0.4} & \multirow[b]{2}{*}{0.4} & \multirow[b]{2}{*}{0.3667} & \multirow[b]{2}{*}{0.667} & \multirow[b]{2}{*}{ No } \\
\hline News shop & & & & & & & & & & & \\
\hline $\begin{array}{l}\text { Food } \\
\text { courts }\end{array}$ & \multirow[b]{2}{*}{ B } & \multirow[b]{2}{*}{0.5} & \multirow[b]{2}{*}{0.6} & \multirow[b]{2}{*}{0.4} & \multirow[b]{2}{*}{0.5} & \multirow[b]{2}{*}{0.5} & \multirow[b]{2}{*}{0.6} & \multirow[b]{2}{*}{0.5} & \multirow[b]{2}{*}{0.5333} & \multirow[b]{2}{*}{0.423} & \multirow[b]{2}{*}{ No } \\
\hline $\begin{array}{l}\begin{array}{l}\text { Plastics } \\
\text { stall }\end{array} \\
\text { Arcade }\end{array}$ & & & & & & & & & & & \\
\hline $\begin{array}{l}\text { Arcade } \\
\text { Hypermark }\end{array}$ & \multirow[b]{2}{*}{ C } & \multirow[b]{2}{*}{0.4} & \multirow[b]{2}{*}{0.3} & \multirow[b]{2}{*}{0.2} & \multirow[b]{2}{*}{0.3} & \multirow[b]{2}{*}{0.5} & & & & & \\
\hline $\begin{array}{l}\text { et } \\
\text { Exhibition } \\
\text { Area }\end{array}$ & & & & & & & 0.4 & 0.5 & 0.4667 & 0.13 & No \\
\hline Location & $\begin{array}{c}\text { Sessio } \\
\mathrm{n}\end{array}$ & & ning & & & & ning & & & $\begin{array}{c}\mathrm{p}- \\
\text { value }\end{array}$ & Sig \\
\hline 2nd floor & Area & S1 & S2 & S3 & Ave. & S1 & S2 & S3 & Ave. & & . \\
\hline Stage & & & & & & & & & & & \\
\hline Bookstore & & & & & & & & & & & \\
\hline $\begin{array}{l}\text { Exhibition } \\
\text { Area }\end{array}$ & A & 0.6 & 0.5 & 0.5 & 0.5333 & 0.6 & 0.5 & 0.6 & 0.5667 & 0.423 & No \\
\hline $\begin{array}{l}\text { Supermark } \\
\text { et }\end{array}$ & & & & & & & & & & & \\
\hline $\begin{array}{l}\text { Eye wear } \\
\text { Shop }\end{array}$ & & & & & & & & & & & \\
\hline $\begin{array}{l}\text { Reload } \\
\text { station }\end{array}$ & B & 0.5 & 0.4 & 0.4 & 0.4333 & 0.7 & 0.9 & 0.8 & 0.8 & 0.05 & Yes \\
\hline $\begin{array}{l}\text { Maxis } \\
\text { center }\end{array}$ & & & & & & & & & & & \\
\hline Bakery & & & & & & & & & & & \\
\hline Lobby & C & 0.5 & 0.6 & 0.3 & 0.4667 & 1.1 & 1 & 1.1 & 1.0667 & 0.035 & Yes \\
\hline
\end{tabular}

\section{FUTURE WORK RECOMMENDATION}

The findings of this study offer insight for future research in this field, which includes:

a. Increasing the size of the sample taken, the types of activities at the mall and personal monitoring and observation of the occupants.

b. The comparison should be done with different malls.

c. Monitoring should cover the entire day, and the tracking result could be identified in a specific time.

d. Monitor the specific parameter of VOCs such as xylene, toluene and any to get accurate sources of emission.

\section{ACKNOWLEDGEMENTS}

The authors wish to thank the shopping mall Ayer Keroh, Malacca and all respondents in providing assistance in this study.

\section{COMPETING INTERESTS}

There is no conflict of interest.

\section{REFERENCES}

1. Hui PS, Mui KW, Wong LT. Influence Of Indoor Air Quality (IAQ) Objectives on AirConditioned offices in Hong Kong, Environment Monitoring Assessment, 2008; vol. 144, pp. 315-322.

2. Turunen $M$, Toyinbo $O$, Putus $T$, et al. Indoor Environmental Quality in School Buildings, and The Health and Wellbeing 
of Students, International Journal of Hygiene and Environmental Health, 2014; vol. 217, pp. 733-9.

3. Amodio M, Dambruoso PR, De Gennaro G, et al. Indoor Air Quality (IAQ) Assessment In A Multi-Storey Shopping Mall By High Spatial Resolution Monitoring Of Volatile Organic Compounds (VOC), Environment Science and Pollution Research International, 2014; 21(23), pp. 1318613195.

4. Tang J, Chan CY, Wang X, et al. Volatile Organic Compounds In A Multi-Storey Shopping Mall In Guangzhou, South China, Atmospheric Environment, 2005;39, pp. 7374-7383.

5. Hasan NH, Said MRS, Leman AM. Health effect from Volatile Organic Compounds and Useful Tools for Future Prevention A Review, International Journal of Environmental Engineering Science and Technology Research, 2013; vol. 1, pp. 2836.

6. Dias PL, Raimondo D, Corgnati SP, et al. Assessment of Indoor Air Quality and Thermal Comfort in Portuguese Secondary Classrooms: Methodology and Results, Building and Environment, 2014; vol. 81, pp. 69-80

7. Senitkova I. Impact of Indoor Surface Material On Perceived Air Quality, Materials Science \& Engineering CMaterials for Biological Applications, 2014; 36, pp. 1-6.

8. Canha N, Almeida SM, Freitas MDC, et al. Particulate Matter Analysis In Indoor Environments Of Urban And Rural Primary Schools Using Passive Sampling Methodology, Atmospheric Environment, 2014; vol. 83, pp. 21-34.

9. Frontczak M, Andersen RV, Wargocki P. Questionnaire Survey on Factors Influencing Comfort With Indoor Environmental Quality in Danish Housing, Building and Environment, 2012; vol. 50, pp. 56-64.

10. Ng LC, Musser A, Persily AK, et al. Indoor Air Quality Analyses of Commercial Reference Buildings, Building and Environment, 2012; vol. 58, pp. 179-187.

11. Dutton SM \& Fisk WJ. Energy and Indoor Air Quality Implications of Alternative Minimum Ventilation Rates in California Offices, Building and Environment, 2014; vol. 82, pp. 121-127.
12. Fabi V, Andersen RV, Corgnati S, et al. Occupants' Window Opening Behaviour: A Literature Review of Factors Influencing Occupant Behavior and Models, Building and Environment, 2012; vol. 58, pp. 188198

13. Hedge A, Erickson WA, Rubin G. Predicting Sick Building Syndrome at the Individual and Aggregate Levels, Pergamon, 1996; vol. 22, pp. 3-19.

14. Lin LY, Chuang HC, Liu IJ, et al. Reducing Indoor Air Pollution by Air Conditioning is Associated With Improvements in Cardiovascular Health Among The General Population, Science of the Total Environment, 2013; vol. 463-464, pp. 176181.

15. Almeida-Silva M, Wolterbeek HT, Almeida SM. Elderly Exposure to Indoor Air Pollutants, Atmospheric Environment, 2014; vol. 85, pp. 54-63.

16. Uhde $E \&$ Salthammer $T$. Impact of Reaction Products from Building Materials and Furnishings on Indoor Air Quality-A Review of Recent Advances In Indoor Chemistry, Atmospheric Environment, 2007; vol. 41, pp. 3111-3128.

17. Bourdin D, Mocho P, et al. Formaldehyde Emission Behavior of Building Materials: On-Site Measurements and Modeling Approach To Predict Indoor Air Pollution, Journal of Hazardous Materials, 2014; vol. 280, pp. 164-173.

18. Sekaran U. Research Methods for Business: A Skill-Building Approach, 3rd ed. 2000 New York: John Wiley and Sons, Inc.

19. Meciarova L, Vilcekova S, Burdova EK, et al. Factors affecting the total Volatile Organic Compound (TVOC) Concentrations in Slovak Households, International Journal of Environmental Research and Public Health 2017; 14, 1443-1469. 